\title{
Electoral spillovers in an intertwined world: Brexit effects on the 2016 Spanish vote
}

\author{
Agelos Delis, ${ }^{1}$ Konstantinos Matakos, ${ }^{2}$ Dimitrios Xefteris ${ }^{3}$
}

Abstract: The Brexit vote took place three days before the June 26, 2016, Spain's parliamentary elections, in which anti-systemic parties performed worse compared to the previous elections (December 2015) despite the optimistic predictions of the pre-election polls. We split the Spanish votes in local ones (casted after Brexit) and postal ones (casted before Brexit) and -by employing a differences-in-differences model a la Montalvo (2011) - we provide causal evidence suggesting that the electoral performance of the anti-systemic parties deteriorated due to the uncertainty/fear caused to the Spanish electorate by the Brexit vote.

\section{Introduction}

On the wake of the Brexit referendum result (Friday, June 24, 2017) IBEX -the main index of the Spanish stock market - fell by 12 percent. Until today, this fall is the biggest single-day drop in its quarter of a century long history. Hence, it is arguably fair to say that Brexit was both not anticipated in Spain and -during that days at least- filled with fear and uncertainty the fragile Spanish economy. A couple of days later (Sunday, June 26, 2016) Spain conducted elections for parliament for a second time within a few months searching a way out of the deadlock (the last election was held in December 2015, but no agreement for the formation of a coalition government could be reached). The polls agreed that the leftist radical alliance between Podemos and Izquierda Unida was not losing its popularity between December 2015 and June 2016 , but in the June 2016 election its vote share fell from about $24.5 \%$ to $21.2 \%$.

\footnotetext{
${ }^{1}$ Corresponding author. Economics, Finance \& Entrepreneurship Department, Aston Business School, Birmingham, UK. Email: a.delis@aston.ac.uk

2 Department of Political Economy, King's College, London, UK. Email: konstantinos.matakos@kcl.ac.uk

${ }^{3}$ Department of Economics, University of Cyprus, Nicosia, Cyprus. Email: xefteris.dimitrios@ucy.ac.cy
} 
Was this unanticipated drop in the support for the radicals' appeal -partially at least-a consequence of the unprecedented short-run uncertainty in the Spanish economy caused by the Brexit vote? Many observers and analysts (e.g Frayer 2016) have argued that voters reasonably reacted to the increasing unpredictability, by refusing to further fuel the fire and gave less power to the radical leftist parties. Indeed, a recent strand of literature which includes, but is not limited to, Klößner and Sekkel (2014), and Balli et al. (2017) has established that national borders are not enough to prevent economic uncertainty spillovers: uncertainty generated in an economy due to an exogenous (or endogenous) incident travels abroad. There are many factors that determine the size and speed of the spillover, with economic integration between the origin and the destination of the contamination being naturally a predominant one. Undoubtedly, the record drop in the IBEX index is a striking indication that the uncertainty generated by the Brexit affected the Spanish markets.

But did it affect the Spanish vote a couple of days later as well? A rational choice theory argument would suggest that it presumably did: rational voters facing a high uncertainty (anti-systemic parties) and a low uncertainty option (systemic parties) should react to an exogenous increase in economic uncertainty by valuing more the less uncertain option. Despite the apparent reason behind this argument, there is so far no evidence that without the shock caused by the Brexit vote, the drop in the radicals' support would not have taken place. This short note aims at filling this gap by providing the first piece of causal evidence in support of the described link.

By exploiting, as a natural experiment, the fact that a part of the Spanish population residing abroad voted before the Brexit vote while locals voted right after Brexit, we find strong indications that Brexit affected the Spanish vote. ${ }^{4}$ This institutional aspect allows us to conduct a differences-in-differences analysis a la Montalvo (2011) and identify the effect on electoral behavior of being exposed to the Brexit realization as opposed to voting without it having

\footnotetext{
${ }^{4}$ Natural experiments are consistently being exploited for the study of a variety of political economy questions. Recent examples include, but are not limited to, Giani (2017), Dinas et al. (2017), Giannetti and Grofman (2011), Ferwerda (2014), Spenkuch and Toniatti (2015), De Melo and Silveira (2011), Lucardi (2017).
} 
occurred. In what follows, first (section 2), we describe our empirical approach and, then (section 3), we discuss our results and their limitations.

\section{Data and empirical approach}

We obtain data for electoral results from the Spanish Ministry of Interiors. We use information for four General Elections 2008, 2011, 2015 and 2016 and two European Elections 2009 and 2014. Our sample contains data for 18 provinces and we have information about the votes of Spanish citizens residing in Spain (Non-CERA votes) and also about votes from Spanish citizens permanently 5 living abroad (CERA votes) for each province. In particular, we know how many votes each party got for each one of these two groups of voters for all the elections mentioned above. Hence, we can organize our data as a panel with six elections and 36 districts (18 NonCERA and 18 CERA).

We define as non-systemic parties all the parties that participated in the Unidos Podemos coalition for the June 2016 election and also left wing, green and nationalist parties from different provinces. For example, political parties like Izquierda Unida in all of its earlier incarnations and Compromís-Q. The left wing nationalist parties we include in our definition are for Catalunia; Esquerra Republicana de Catalunya in its all different formats over the years and for the Basque Country; Euskal Herria Bildu. Other examples of left wing and green nationalist parties are Europa de los Pueblos-Verdes, a coalition of nationalist parties from Catalunia, Basque Country, Aragon, Galicia, Balearic Islands and Castilla y León. Table 1 summarizes our definition of non-systemic parties as it evolves over time.

There are other political parties that can be described as non-systemic. But our definition attempts to capture: a) parties that appear not to be part of the political establishment and b) political parties that had a significant presence in the Spanish political scene, i.e. had elected MPs or MEPs.

\footnotetext{
${ }^{5}$ There is another category of voters that are temporarily abroad (ERTAS; 14,810 votes in total for 2016) and vote by post or at Spanish consulates abroad, but their votes are counted together with the domestic postal votes and no information is provided about the party that they voted.
} 


\begin{tabular}{|c|c|c|}
\hline Election & & Parties \\
\hline $\begin{array}{l}\text { General } \\
2008\end{array}$ & Elections & $\begin{array}{l}\text { Izquierda Unida (IU) } \\
\text { Esquerra Republicana de Catalunya (ERC) }\end{array}$ \\
\hline $\begin{array}{l}\text { European } \\
2009\end{array}$ & Elections & $\begin{array}{l}\text { La Izquierda (IU-ICV-EUiA-BA) } \\
\text { Europa de los Pueblos-Verdes (Edp-V) }\end{array}$ \\
\hline $\begin{array}{l}\text { General } \\
2011\end{array}$ & Elections & $\begin{array}{l}\text { AMAIUR } \\
\text { Compromís-Q } \\
\text { Esquerra Republicana } \\
\text { La Izquierda Plural (IU-LV) }\end{array}$ \\
\hline $\begin{array}{l}\text { European } \\
2014\end{array}$ & Elections & $\begin{array}{l}\text { Podemos } \\
\text { La Izquierda Plural } \\
\text { Primavera Europea } \\
\text { Los Pueblos Deciden (LPD) } \\
\text { L'Esquerra pel Dret a Decidir (EPDD) }\end{array}$ \\
\hline $\begin{array}{l}\text { General } \\
2015\end{array}$ & Elections & $\begin{array}{l}\text { En Comú } \\
\text { Podemos } \\
\text { Unidad Popular: Izquierda Unida, Unidad Popular en Común } \\
\text { Euskal Herria Bildu } \\
\text { Podemos-En Marea } \\
\text { Podemos-Compromís } \\
\text { Esquerra Republicana de Catalunya - Catalunya Sí (ERC-CATSI) }\end{array}$ \\
\hline $\begin{array}{l}\text { General } \\
2016\end{array}$ & Elections & $\begin{array}{l}\text { En Marea } \\
\text { En Comú Podem } \\
\text { Unidos Podemos } \\
\text { Euskal Herria Bildu } \\
\text { Compromís-Podemos } \\
\text { Esquerra Republicana de Catalunya - Catalunya Sí (ERC-CATSI) }\end{array}$ \\
\hline
\end{tabular}


Our approach tries to identify and estimate whether Brexit caused a change on the voting behavior of the Spanish electorate from non-systemic towards systemic parties, because of the increased uncertainty. As explained above, we have information about the political parties that voters abroad (CERA vote) chose and also for voters in Spain (Non-CERA vote). The voters that were permanently residing abroad could vote either by post until the $21^{\text {st }}$ of June or by casting the vote at a ballot in the embassies and consulates of Spain around the world initially for the days $22^{\text {nd }}$ to $24^{\text {th }}$ of June. ${ }^{6}$ Our identification strategy attempts to exploit the fact that the vast majority of CERA voters did not know about the outcome of the Brexit vote when they casted their votes, compared to the voters in Spain who voted after the release of the Brexit result.

By splitting the Spanish electorate between standard votes cast on Sunday, June 26 2016, (residents' districts) and votes which were mainly cast days before Brexit (non-residents' districts), we construct a difference-in-differences empirical model a la Montalvo (2011) and we identify the causal effect of the Brexit result on the trend of the vote share of the leftist alliance.

$$
Y_{s, t}=a+\beta_{t}+\gamma_{s}+\sum_{t=2009}^{2016} \delta_{t}\left(T_{t} V_{s}\right)+u_{s, t}
$$

$Y_{s, t}$ takes the value one if the cumulative vote-share of anti-systemic parties in district $s$ in current elections (period $t$ ) increased compared to the previous elections (period $t-1$ ) and the value zero other-wise, $\beta_{t}$ and $\gamma_{s}$ are a time and district dummies respectively, $V_{s}$ is a dummy that takes the value of one if district $s$ is a Non-CERA one (i.e. it is treated) and zero otherwise, $T_{t}$ is a dummy that takes the value of one if the year is $t$ and is zero for all other years, and $u_{s, t}$ is the error term.

\footnotetext{
${ }^{6}$ An extension was granted until the $26^{\text {th }}$ of June by the Spanish Electoral Office due to delays for CERA voters in receiving the necessary paperwork that would allow them to cast their votes. This might have "contaminated" our data since we did not have initially information whether the CERA votes were casted by post prior to the $21^{\text {st }}$ of June or were casted at urns in Spanish consulates potentially after the $24^{\text {th }}$ of June. But finally we gathered from a sizeable sample of Spanish consulates a breakdown of their votes by post and urn. It turned out that $65 \%$ of these CERA votes were casted by post implying that if some contamination took place it must have been of a very low degree. In any case, even if it took place, it makes our main point stronger for the reason that increases the likelihood CERA voters voted against anti-systemic parties and hence making our estimates a low bound.
} 


\section{Results}

The results back the idea that that turbulence caused by Brexit costed Unidos Podemos an increase in their vote-share, and a potential key role in government formation. In the first column of Table 2, it is evident that there is a negative causal effect of Brexit on the electoral performance of anti-systemic parties in the Spanish General Election of 2016 since the coefficient of interest (the one that refers to the interaction Non-CERA * 2016) is highly statistically -and electorallysignificant. Furthermore, by including treatment leads to check for pre-trends (see e.g., Autor 2003) we can verify that the parallel trends assumption prior to treatment is clearly satisfied, since all pre-treatment differences for the control and treated groups are statistically not significant (Angrist and Pischke 2009). Notably, this differential effect of residents' versus nonresidents' districts on the trend of anti-systemic electoral performance exists only for the 2016 elections. In other words, the required parallel trends hypothesis, that is required for the differences-in-differences approach, is found to hold, allowing a causal interpretation of the results.

The reason why we prefer to focus on trends rather than absolute measures of electoral performance is because the Spanish political system went through some dramatic institutional and party-system structural changes throughout the past years. Despite this, we note that any alternative absolute measure yields the same result with respect to the 2016 elections (antisystemic parties performed differentially worse in the resident's districts compared to nonresidents' districts), while, naturally, the placebo tests regarding the previous electoral races are meaningless given that anti-systemic vote shares increased from about $5 \%$ in 2008 to above $25 \%$ in 2015 and, more importantly, the composition of non-resident's districts dramatically changed in 2009 (their size was reduced by more than 90\%). For instance, in column 2 of Table 2 we substitute our dependent variable with the cumulative vote-share of anti-systemic parties and we find exactly this. The Brexit effect is still significant but the interaction referring to the previous election also becomes relevant since it captures the political system transformation. 


\section{Table 2: The Effect of Brexit on Spanish Election}

\begin{tabular}{lcc}
\hline \hline Dependent variable & $\begin{array}{c}\text { Rise of anti- } \\
\text { systemic vote }\left(Y_{S, t}\right)\end{array}$ & $\begin{array}{c}\text { Vote share of anti- } \\
\text { systemic parties }\end{array}$ \\
\hline Treatment effect $($ Non-CERA * 2016) & $(1)$ & $(2)$ \\
\hline Placebo tests & -0.222 & -0.116 \\
Non-CERA * 2015 & $(0.105)^{* *}$ & $(0.025)^{* * *}$ \\
& & -0.090 \\
Non-CERA * 2014 & -0.167 & $(0.022)^{* * *}$ \\
& $(0.105)$ & 0.038 \\
Non-CERA * 2011 & 0.000 & $(0.023)$ \\
& $(0.023)$ & -0.013 \\
Non-CERA * 2009 & -0.055 & $(0.018)$ \\
$N$ & $(0.095)$ & 0.001 \\
Fixed effects & -0.111 & $(0.007)$ \\
\hline \hline
\end{tabular}

$$
{ }^{*} p<0.10 ; * * p<0.05 ; * * * p<0.01
$$

Note: Robust standard errors reported in parentheses in columns 1 and 2; cluster bootstrapped standard errors (20,000 replications) were also constructed, but results remained mostly similar. Treatment lags, election year and region fixed effects included in all specifications.

Indeed, in such a volatile -institutionally and politically- environment, a rough-cut dependent variable like the trend (increase versus decrease) of anti-systemic parties' electoral performance seems as the obvious choice in order to compare political behavior from one election to another in a meaningful manner. Of course, the fact that the environment in which this natural experiment takes place, went through such important transformations during the recent years, calls for extreme caution: a pre-2016 stable institutional and political framework would definitely 
provide additional confidence. But, regardless of the existing limitations and objective obstacles, our analysis provides a strong first indication of a causal link between Brexit and the result of the Spanish elections, and will hopefully serve as a starting point for subsequent full-fledged studies of spillovers among interconnected political entities.

Our results, beyond supporting popular conjectures made -among others - by the press and many academics, also admit a wider interpretation. In our intertwined world attempts to restore last century's -partial, at most-national isolation are at least very difficult to achieve, if not almost impossible.

\section{References}

Angrist, J.D, and Pischke, J-S. (2009). Mostly Harmless Econometrics: An Empiricist's Companion. Princeton: Princeton University Press.

Autor, D. (2003). Outsourcing at Will: The Contribution of Unjust Dismissal Doctrine to the Growth of Employment Outsourcing. Journal of Labor Economics, 21(1): 1-42.

Balli, F., Uddin, G. S., Mudassar, H., \& Yoon, S. M. (2017). Cross-country determinants of economic policy uncertainty spillovers. Economics Letters, 156, 179-183.

Da Silveira, B. S., \& De Mello, J. M. (2011). Campaign advertising and election outcomes: Quasinatural experiment evidence from gubernatorial elections in Brazil. The Review of Economic Studies, 78(2), 590-612.

Dinas, E., Matakos, K., Xefteris, D., and Hangartner, D. (2017). “Waking Up the Golden Dawn: Does Exposure to the Refugee Crisis Increase Support for Far-right Parties?", mimeo

Ferwerda, J. (2014). Electoral consequences of declining participation: A natural experiment in Austria. Electoral studies, 35, 242-252. 
Frayer, L. (2016). How Brexit affected Spain's election. Los Angeles Times, 27 June. http://www.latimes.com/world/europe/la-fg-spain-election-snap-story.html

Giani, M. (2017). “Don't Ban the Muslims: Public Reaction to Terror Attacks”, mimeo

Giannetti, D., and Grofman, B. (2011). A Natural Experiment on Electoral Law Reform: Evaluating the Long Run Consequences of 1990s Electoral Reform in Italy and Japan. New York: Springer

Klößner, S., \& Sekkel, R. (2014). International spillovers of policy uncertainty. Economics Letters, $124(3), 508-512$.

Lucardi, A. (2017). The Effect of District Magnitude on Electoral Outcomes. Evidence from Two Natural Experiments in Argentina. British Journal of Political Science, forthcoming.

Montalvo, J. G. (2011). Voting after the bombings: A natural experiment on the effect of terrorist attacks on democratic elections. Review of Economics and Statistics, 93(4), 1146-1154.

Spenkuch, J.L., and Toniatti, D. (2015). Political Advertising and Election Outcomes. Barcelona GSE working paper. 